\author{
Proceedings of the ASME 2019 \\ 2nd International Offshore Wind Technical Conference \\ IOWTC2019
}

November 3-6, 2019, St. Julian's, Malta

IOWTC2019-7564

\title{
WINDCRETE FATIGUE VERIFICATION
}

\author{
Pau Trubat ${ }^{1}$, Jesús Bairan, Adrián Yagüe, Climent Molins \\ Universitat Politècnica de Catalunya - BarcelonaTech, \\ Department of Civil and Environmental Engineering \\ Barcelona
}

\section{ABSTRACT}

WindCrete is an offshore concrete spar type platform for Wind Turbines developed at Universitat Politècnica de Catalunya - BarcelonaTech. The main characteristics of the platform are its monolithic configuration and the use of concrete as main material. The monolithic nature allows avoiding joints between the substructure and the tower increasing the service life of the structure. The use of concrete increases the resistance when exposed to an offshore environment but requires ensuring a full compression state along the structure to avoid cracking. Thus, the platform is post-tensioned by longitudinal tendons along its length.

Adequate fatigue design is a key factor to ensure the reliability of offshore structures. Floating Offshore Wind Turbines are subjected to cyclic phenomena coming from waves, wind, rotor-induced vibrations and structural vibrations. These loads have to be considered in order to assess the fatigue life of offshore structures. Furthermore, pre-stressed concrete adds an internal load such that it avoids the presence of tension stresses at any given section, which has a positive influence on the fatigue response of the structure by increasing its fatigue resistance. An excess of compression can, however, also induce an adverse effect on the fatigue resistance of the concrete.

In order to study the fatigue behaviour of WindCrete when fitted with a 5MW Wind Turbine, a Fatigue Limit State verification is performed according to the DNVGL-ST-0437 for load cases definition and FIB Model Code (2010) for fatigue structural verification. The location chosen to install WindCrete is the Gulf de Lion, at the west of the Mediteranian Sea off the coast of Catalunya with a mean wind speed above $9 \mathrm{~m} / \mathrm{s}$. The metocean conditions for design purpose are presented, which are obtained from available environmental data.

A total of 458 simulation cases are performed using the NREL FAST software assuming wind and wave co-directionally, and quasi-static mooring response for Parked and PowerProduction operational modes. Assuming an elastic response of the tower, the internal stresses at the tower base are obtained for all the simulations. Then, a fatigue analysis is performed at the tower base through a cumulative damage approach based on the Palmgren-Miner rule. The analysis accounted for the multiaxial stresses produced by the combination of axial, bending and tangential forces. The $S-N$ material curves were defined according to the Model Code 2010 method, which accounts for the effect of the stress range as well as the average stress.

Keywords: FOWT, Wind Turbine, Floating, Concrete, Fatigue, WindCrete

\section{NOMENCLATURE}

$\begin{array}{ll}\text { A } & \text { Cross Section Area } \\ \mathrm{C}_{33} & \text { Heave Hydrostatic Stiffness } \\ \mathrm{C}_{44} & \text { Roll Hydrostatic Stiffness } \\ \mathrm{C}_{55} & \text { Pitch Hydrostatic Stiffness } \\ \mathrm{CB} & \text { Center of Buoyancy } \\ \mathrm{CM} & \text { Center of Mass } \\ \mathrm{D} & \text { Damage } \\ \text { DLC } & \text { Design Load Case } \\ f_{c k} & \text { Concrete Characteristic Strength } \\ \text { FLS } & \text { Fatigue Limit State } \\ F_{Z} & \text { Axial Force } \\ \text { FOWT } & \text { Floating Offshore Wind Turbine } \\ H_{S} & \text { Significant Wave Height } \\ \text { I } & \text { Second Moment of Area } \\ \mathrm{I}_{44} & \text { Platform Roll Inertia } \\ \mathrm{I}_{55} & \text { Platform Pitch Inertia } \\ \mathrm{I}_{66} & \text { Platform Yaw Inertia } \\ \text { LC } & \text { Load Case }\end{array}$

${ }^{1}$ Contact author: pau.trubat.casal@upc.edu 


$\begin{array}{ll}\text { MSL } & \text { Mean Sea Level } \\ M_{x} & \text { Bending Moment } x \text { direction } \\ M_{y} & \text { Bending Moment } y \text { direction } \\ P & \text { Prestressing force } \\ \text { RNA } & \text { Rotor and Nacelle Assembly } \\ T_{P} & \text { Wave Peak Period } \\ \mathrm{U} & \text { Wind mean Velocity } \\ \theta_{\text {wave }} & \text { Wave direction } \\ \theta_{\text {wind }} & \text { Wind direction }\end{array}$

\section{INTRODUCTION}

The success FOWT technology is highly dependent on its reliability and its life span capabilities such that the viability of producing energy is guaranteed through lower operational and maintenance costs. Steel alternative materials such as concrete have been used by the offshore industry extensively proving its reliability and achieving, in some cases, a durability of over 60 years [1,2].

The use of concrete in FOWT as main material is proposed by WindCrete [3] and also being tested at full scale in FloatGen platform [4].

The reliability of floating structures relies mainly on the structure's fatigue resistance to cyclic loads induced by stochastic wave and wind actions as well as the durability of the material. Durability of concrete structures is ensured by a high quality construction process and allocating sufficient cover depth to protect the reinforcement. On the other hand, fatigue resistance should be verified by the FLS which accounts for the stress range and mean value that the concrete has to withstand during its service life. A Life Cycle Analysis of the Windcrete also highlighted the interest of the use of concrete [5].

Current concrete fatigue models are based on the S-N Curves or on Continuous Damage models. The S-N curves, also known Wöhler's curves, adopted by EuroCode2 [6], FIB Model Code [7] or DNVGL-ST-C502 [8], are the single most common used method. The S-N curves method bases its calculation procedure on the maximum stress level on the structure. However, in order to translate these into real fatigue results a damage accumulation procedure is needed [9]. Palmgren-Miner, which assumes damage accumulates in a linear manner, is the most used and extended fatigue damage accumulation rule. However, no multiple points are taken into account simultaneously, and therefore, stress redistribution processes are omitted. On the other hand, FIB Model Code includes a reduction coefficient $\eta_{c}$ based on the stress distribution of the studied cross-section, which accounts for the beneficial effects of the stress redistribution. Continuous damage models consider the fatigue damage evolution obtained from simulations which modifies the section characteristics and material properties during the simulations. The change of the material properties and section characteristics can result in a significant reduction of the service life.

WindCrete is a monolithic concrete spar platform for wind turbines developed at Universitat Politècnica de Catalunya BarcelonaTech [10]. The concrete structure is prestressed by tendons to ensure a complete compression state at any point of the structure during its entire intended service life which is set to 50 years. The FLS has to be assessed to ensure appropriate design and adequate reliability. The platform is to be installed in the Mediterranean Sea at a $250 \mathrm{~m}$ water depth site in the north east of Catalonia, at the Gulf de Lion.

The paper focusses on the fatigue design of the WindCrete platform and its main aspects. The DLC analyzed are based on DNVGL-ST-0437 [11] which establish the procedure to define the NSS Joint probability distribution of $H_{s}, T_{p}$ and $U$ at hub height. The metocean data is obtained from Puertos del Estado SIMAR database [12] for the long term wave climate characterisation. The DLC analysed are the DLC 1.2 of power production design situation and the DLC 6.4 for parked conditions. Design conditions such as power production plus occurrence of fault, start up, normal shut-down, or parked and fault conditions are disregarded.

First, the main properties of the platform are presented followed by the metocean data. Then, the procedure to obtain the forces according to the LC and the subsequent fatigue analysis is outlined. Furthermore, a sensitivity analysis is performed on the influence of the characteristic compressive concrete strength on the fatigue life of the structure. Finally, conclusions are presented focusing on the damage of the structure and its estimated life span.

\section{WINDCRETE PLATFORM AND MODEL}

The WindCrete platform object of this study is dimensioned to support the NREL 5MW reference wind turbine [13] and withstand wind and waves loads whilst ensuring good performance of the turbine in Power Production state. A sketch of the WindCrete platform is shown in Figure 1. The full structure of WindCrete is $87.6 \mathrm{~m}$ tall from the MSL and has a draft of $130 \mathrm{~m}$. The buoy is composed of a tapered section above a cylindrical section. The cylinder has a diameter of $13 \mathrm{~m}$ and a thickness of $0.5 \mathrm{~m}$ and the taper section has a lower diameter of $13 \mathrm{~m}$ and an upper diameter of $10 \mathrm{~m}$ at MSL with a constant thickness of $0.5 \mathrm{~m}$. The tower starts at the MSL and has a top diameter of $4 \mathrm{~m}$ at the yaw bearing and a mean thickness of 0.4 $\mathrm{m}$. The ballast added to achieve a suitable Pitch/Roll hydrostatic stiffness has a mass of 8340 Tones and consists on an aggregate with a specific weight of $25 \mathrm{kN} / \mathrm{m}^{3}$ located at the bottom of the cylinder. The main properties of the platform are summarized in Table 1 . The inertia terms of Table 1 are assessed from the CM and include the RNA. The hydrostatic stiffness values also account for the weight. More detailed definition of WindCrete can be found in [10].

The WindCrete platform has a design depth of $250 \mathrm{~m}$. The mooring system is designed to ensure station-keeping of the floating platform whilst providing sufficient stiffness in surge, sway and yaw to ensure a proper behavior of the platform. The mooring system consists of three catenary lines spaced $120^{\circ}$ apart with a delta line connection to the buoy to provide additional yaw stiffness to the system. The fairleads are located at $-70 \mathrm{~m}$ depth and the radius to the anchor at seabed is of 750 $\mathrm{m}$. Each line is composed by a chain segment in contact with the seabed, a wire segment and two delta segments. Also a dead 
weight is placed in the connection between the chain and the steel wire. Table 2 shows the main characteristics of the line.

TABLE 1: WINDCRETE MAIN PROPERTIES

\begin{tabular}{|c|c|}
\hline Displaced volume [m³] & $1.69 \mathrm{E}+04$ \\
\hline Draft [m] & 130 \\
\hline Concrete mass [kg] & $8.71 \mathrm{E}+06$ \\
\hline Ballast [kg] & $8.34 \mathrm{E}+06$ \\
\hline Wind turbine mass [kg] & $3.50 \mathrm{E}+05$ \\
\hline CM $[\mathrm{m}]$ & 53.34 \\
\hline CB [m] & 63.97 \\
\hline Metacentric [m] & 10.57 \\
\hline Total Mass [kg] & $1.74 \mathrm{E}+07$ \\
\hline$I_{44}\left[\mathrm{~kg} \cdot \mathrm{m}^{2}\right]$ & $5.74 \mathrm{E}+10$ \\
\hline$I_{55}\left[\mathrm{~kg} \cdot \mathrm{m}^{2}\right]$ & $5.74 \mathrm{E}+10$ \\
\hline$I_{66}\left[\mathrm{~kg} \cdot \mathrm{m}^{2}\right]$ & $4.21 \mathrm{E}+08$ \\
\hline $\mathrm{C}_{33}[\mathrm{~N} / \mathrm{m}]$ & $7.90 \mathrm{E}+05$ \\
\hline $\mathrm{C}_{44}[\mathrm{~N} \cdot \mathrm{m} / \mathrm{rad}]$ & $1.71 \mathrm{E}+09$ \\
\hline $\mathrm{C}_{55}[\mathbf{N} \cdot \mathbf{m} / \mathrm{rad}]$ & $1.71 \mathrm{E}+09$ \\
\hline
\end{tabular}

WindCrete behavior is modelled using FAST, an aero-servohydro-elastic simulation tool. The properties of WindCrete are reflected in the model by adjusting all the relevant input parameters spread across the different FAST modules. The aerodynamics module accounts for tip and hub losses as well as for the tower shadow. Hydrodynamics are determined from a hydrostatic stiffness matrix and wave loads computed only using Morison's equation [14]. Also an additional linear damping of $8.3 \mathrm{~N} /(\mathrm{m} / \mathrm{s})$ is applied in heave direction. Table 3 shows the Morison hydrodynamic coefficients used in FAST, which were calibrated from the experimental data of WindCrete scale model $[15,16]$.

TABLE 2: WINDCRETE MOORING SYSTEM MAIN PROPERTIES

\begin{tabular}{|lr}
\hline Radius to anchor [m] & 750 \\
\hline Chain line length [m] & 471.5 \\
\hline Wire line length [m] & 250 \\
\hline Delta line length [m] & 60 \\
\hline Chain wet weight [N/m] & 275 \\
\hline Steel wire wet weight [N/m] & 67.2 \\
\hline Delta wet weight [N/m] & 67.2 \\
\hline Dead weight [N] & $4.5 \mathrm{E}+04$ \\
\hline
\end{tabular}

TABLE 3: FAST MORISON HYDRODYNAMIC COEFICIENTS

\begin{tabular}{|l|r|r|r} 
& Cd & Ca & Cp \\
\hline Base (Axial direction) & 2.4 & 1 & 1 \\
\hline Cylinder & 0.8 & 1 & 1 \\
\hline Transition piece & 0.8 & 1 & 1 \\
\hline
\end{tabular}
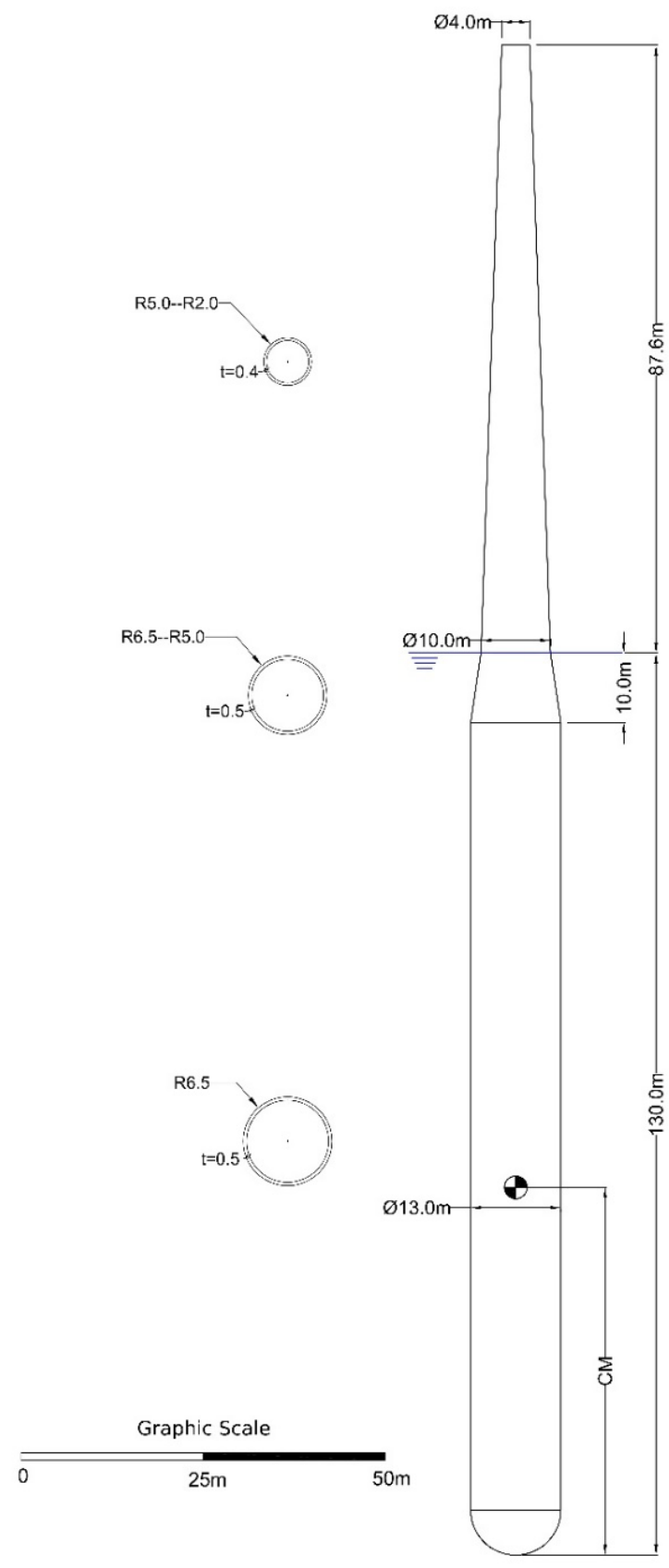

FIGURE 1: WINDCRETE SKETCH AND MAIN DIMENSIONS [10] 


\section{METOCEAN DATA}

The metocean parameters dataset responds to the Puertos del Estado SIMAR database. The exact set of data used corresponds to the SIMAR 2126144 hindcast model point. It corresponds to a location with coordinates $3.50^{\circ} \mathrm{E} 42.00^{\circ} \mathrm{N}, 25$ $\mathrm{km}$ and $40 \mathrm{~km}$ away from the ports of l'Estartit port and Roses cities respectively. Figure 2 shows the location and the mean wind resources at that location. The data of the hindcast is presented each hour and define the $\boldsymbol{H}_{\boldsymbol{s}}, \boldsymbol{T}_{\boldsymbol{p}}, \boldsymbol{\theta}_{\text {wave }}, \boldsymbol{U}$ and $\boldsymbol{\theta}_{\text {wind }}$.

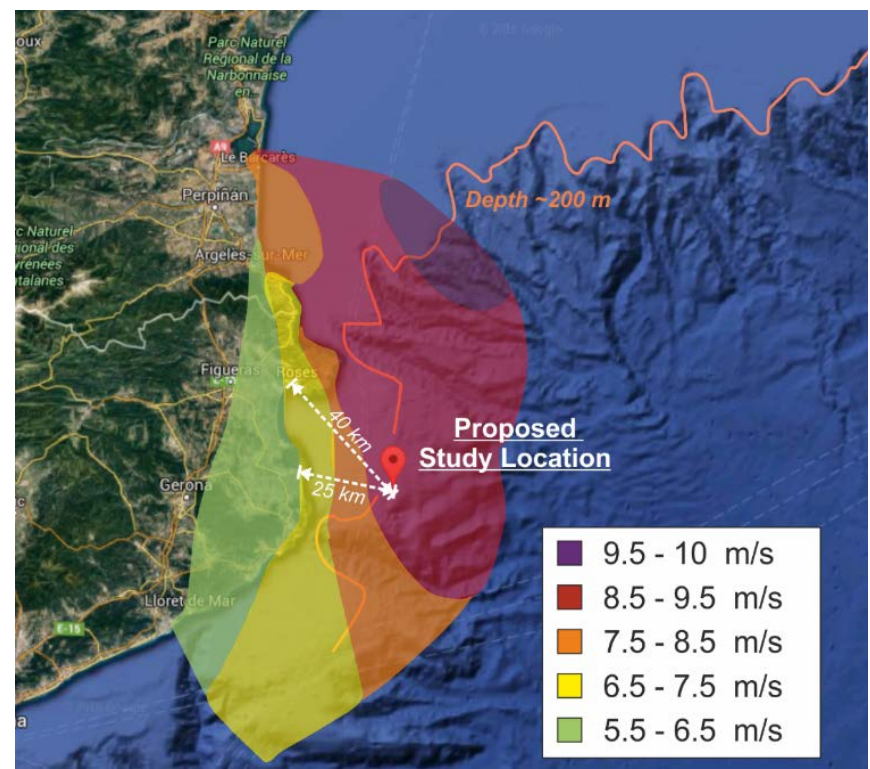

FIGURE 2: LOCATION AND WIND RESOURCE

Wave and wind are considered coodirectional and distributed in 16 directions of $22.5^{\circ}$ each. Figure 3 show the Wind Rose of the selected location and the chosen directions. The significant wave height is discretized each $0.7 \mathrm{~m}$ with a minimum value of $0.3 \mathrm{~m}$, the wave peak period and the mean wind velocity, with a minimum value of $1 \mathrm{~m} / \mathrm{s}$, are discretized with step sizes of $0.5 \mathrm{~s}$ and $2 \mathrm{~m} / \mathrm{s}$ respectively. The selected sea states for the description of the NSS are obtained through a longterm wave climate characterization with a probability of occurrence larger than 1.1E-4, which implies a one hour storm per year.

The total number of sea states obtained were 458, which includes power production and parked wind turbine states. The joint probability of the significant wave height and the mean wind velocity is presented in Figure 4.

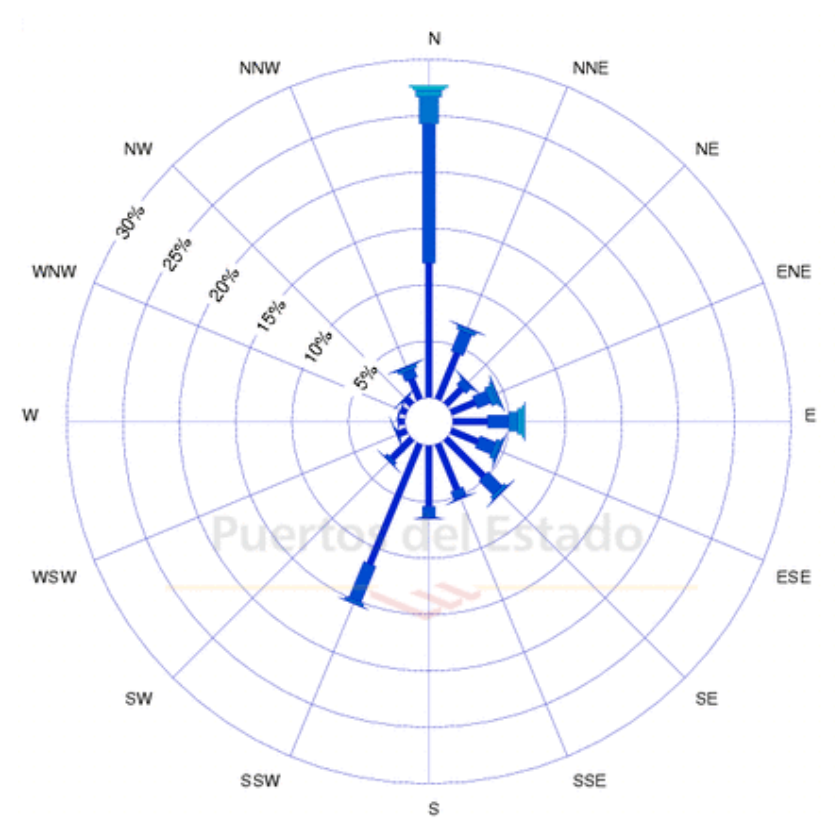

FIGURE 3: WIND ROSE AT THE WINDCRETE LOCATION

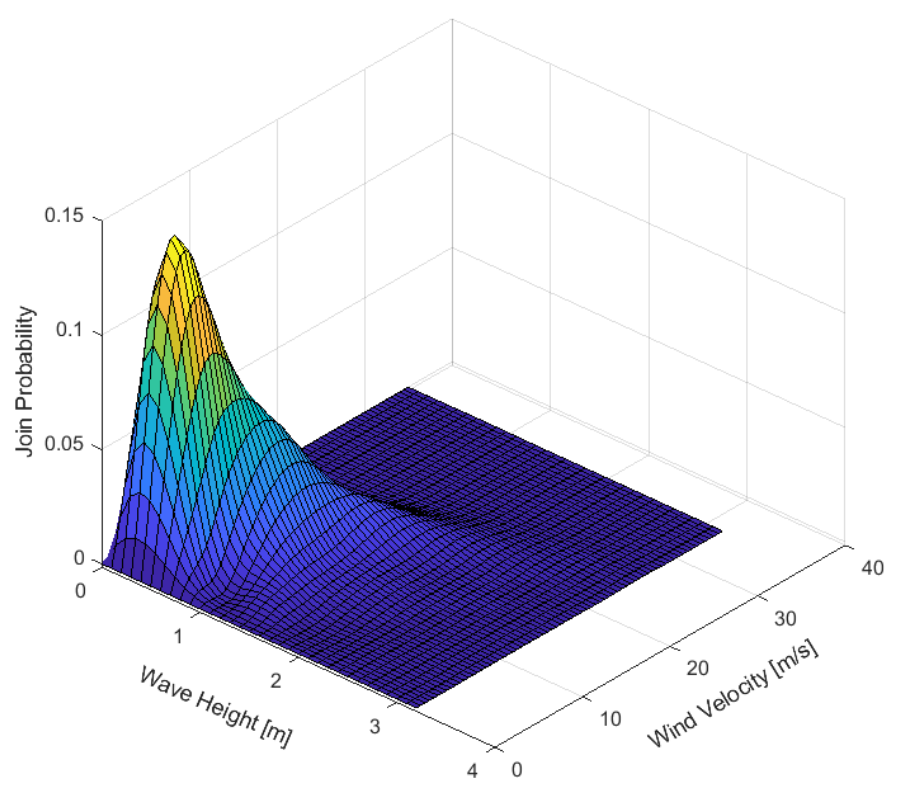

FIGURE 4: WAVE-WIND JOIN PROBAILITY DISTRIBUTION

\section{SIMULATION PROCEDURE}

458 LC were run for every sea state obtained which includes a series of six 10-minutes simulations with varying random seed. A total of 2748 simulations were executed and the initial conditions were adjusted in order to reduce the starting transient time. Consistently, one minute was erased in all simulations. The nomenclature used for the simulations is LCX.Y, with X from 1 to 458 for each sea state, and Y from 1 to 6 for each wind seed used. 
Simulations were run using FAST and the requested output were: platform motions; nacelle accelerations at the yaw bearing; and internal loads at the tower base which according to [17] is the most critical section to fatigue damage. At this specific location of the buoy, the axial force $F_{z}$ and the bending moments $M_{x}$ and $M_{y}$ due environmental loads as well as the weight of the structure were obtained and will serve as input for the subsequent fatigue analysis of the cross-section. Figure 5 shows the surge and pitch motion for the LC32.1, with a $U$ of $15 \mathrm{~m} / \mathrm{s}$, a significant wave of $2.48 \mathrm{~m}$ and a peak period of $4.75 \mathrm{~s}$. Figure 6 shows for the same LC the total tower base moment.

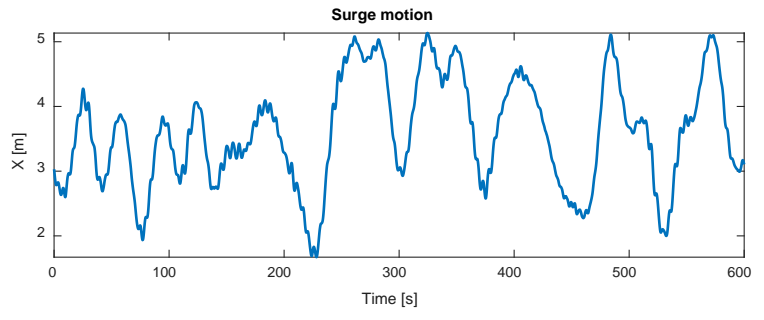

Pitch motion

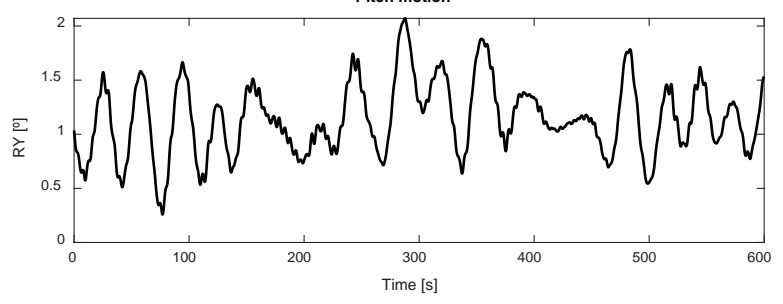

FIGURE 5: SURGE AND PITCH MOTION FOR LC32.1

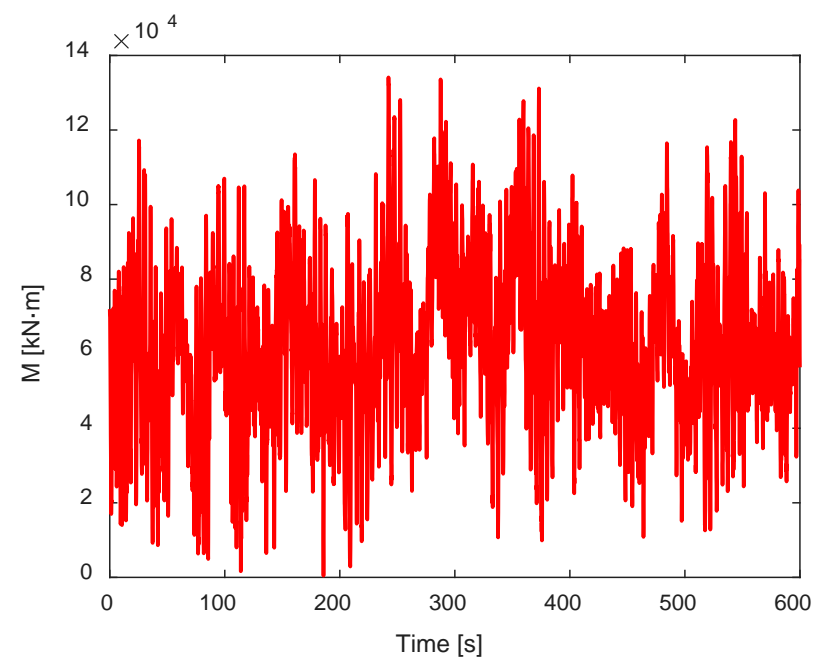

FIGURE 6: MOMENT AT TOWER BASE FOR LC32.1

From the internal loads obtained through FAST the normal stresses at the tower base will be computed according to Eq (1). The prestressed load at the base tower is added to get the overall stresses at that section. The post-tensioning force at the tower base $(P)$ is $2.05 \cdot \mathrm{E}+05 \mathrm{kN}$ considering a $20 \%$ of loses [10]. The external radius at the base tower section $(R)$ is $5 \mathrm{~m}$ and its thickness $(t) 0.5 \mathrm{~m}$. The main parameters of the tower base section used for the stress analysis are shown in Table 4. The normal stress is computed at 16 different circumferential points of the section, as shown in Figure 7, corresponding to wind and waves loading directions. Parameters $x, y$ are the coordinates of the cross section point where the normal stress is desired.

$$
\sigma=\frac{M_{x}}{I} y+\frac{M_{y}}{I} x+\frac{F_{z}}{A}+\frac{P}{A}
$$

where $\sigma$ is the normal stress, $M_{x}$ and $M_{y}$ are the bending moments in $x$ and $y$ directions, $F_{z}$ is the axial force, $P$ is the prestressing force, $I$ the second moment of area, and $A$ the cross section area.

TABLE 4: TOWER BASE CROSS-SECTION PROPERTIES

\begin{tabular}{llr}
\hline Radius & $\mathrm{R}[\mathrm{m}]$ & 5.00 \\
\hline Thickness & $\mathrm{t}[\mathrm{m}]$ & 0.50 \\
\hline Section & $\mathrm{A}\left[\mathrm{m}^{2}\right]$ & 14.92 \\
\hline $\begin{array}{l}\text { Second moment } \\
\text { of Area }\end{array}$ & $\mathrm{I}\left[\mathrm{m}^{4}\right]$ & 169.8 \\
\hline
\end{tabular}

In order to assess the damage of the tower base section a cycle counting method is required due to the stochastic nature of the stresses produced by wave and wind loads. The cycle counting is performed using the rainflow algorithm based on ASTM standard [18]. The rainflow method provides the distribution of the stress time evolution on a number of cycles, each of them associated with the mean stress value and its value range.

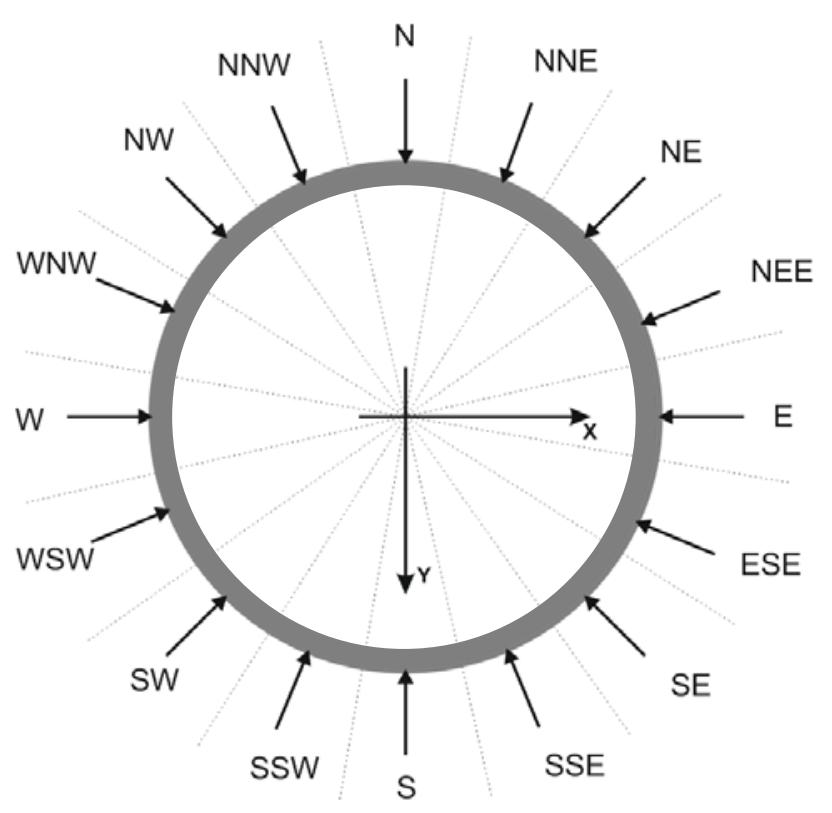

FIGURE 7: WINDCRETE CROSS SECTION 


\section{FATIGUE ANALYSIS}

The fatigue analysis is performed according to the Model Code 10 standardization rules. The total damage is assessed by the Palmgren-Miner linear addition rule expressed in Eq. (2)

$$
D=\sum_{i=1}^{m} \frac{n_{i}}{N_{i}}<D_{\text {lim }}
$$

where $i$ denotes the index of the stress block, $m$ is the index defining the total number of defined stress blocks, $n_{i}$ is the number of the acting stress cycles for the block $i, N_{i}$ denotes the number of resisting cycles for the stress level of the block $i$, and $D_{l i m}$ is the maximum fatigue damage allow for the structural component analyzed.

The fatigue compressive strength of the concrete used in WindCrete is of $36.3 \mathrm{MPa}$ and it follows from Eq. (3) assuming a concrete characteristic compressive strength $\left(f_{c k}\right)$ of $80 \mathrm{MPa}$.

$$
f_{c d, f a t}=0.85 \beta_{c c}(t) f_{c k}\left(1-\frac{f_{c k}}{400}\right) \frac{1}{\gamma_{c, f a t}}
$$

where $\beta_{c c}$ is the function that describes the development of the compressive strength in time, taken as 1 because is the most restrictive value due to the uncertainties when WindCrete would be launched, and $\gamma_{c, f a t}$ is the partial safety load factor for concrete that takes a value of 1.5 .

The number of cycles $\mathrm{N}$ resisted for a stress range, between $S_{c d, \text { min }}$ and $S_{c d, \text { max }}$, can be assessed through Eq(4)-Eq(6), where the expression changes for $\log _{10}(N)=8$. Where $\gamma_{E d}$ is the design load factor and takes a value of 1.1 , and $\eta_{c}$ is the redistribution factor proposed by FIB Model Code [7].

$$
\begin{gathered}
\log _{10}(N)=\log _{10}\left(N_{1}\right)= \\
=\frac{8}{Y-1}\left(S_{c d, \text { max }}-1\right) \quad \text { if } \log _{10}\left(N_{1}\right) \leq 8 \\
\log _{10}(N)=\log _{10}\left(N_{2}\right)=8+\frac{8 \ln (10)}{Y-1}\left(Y-S_{c d, \text { min }}\right) \\
\cdot \log _{10}\left(\frac{S_{c d, \text { max }}-S_{c d, \text { min }}}{Y-S_{c d, \text { min }}}\right) \text { if } \log _{10}\left(N_{1}\right)>8 \\
S_{c d, \text { min }}=\frac{\gamma_{E d} \sigma_{c, \text { min }} \eta_{c}}{f_{c d, f a t}} \\
S_{c d, \text { max }}=\frac{\gamma_{E d} \sigma_{c, \text { max }} \eta_{c}}{f_{c d, f a t}} \\
Y=\frac{0.45+1.8 \cdot S_{c d, \text { min }}}{1+1.8 \cdot S_{c d, \text { min }}-0.3 \cdot S_{c d, \text { min }}^{2}}
\end{gathered}
$$

Figure 8 shows the S-N curves used for different ranges of mean stress and stress ranges for the $80 \mathrm{MPa}$ compressive strength concrete.

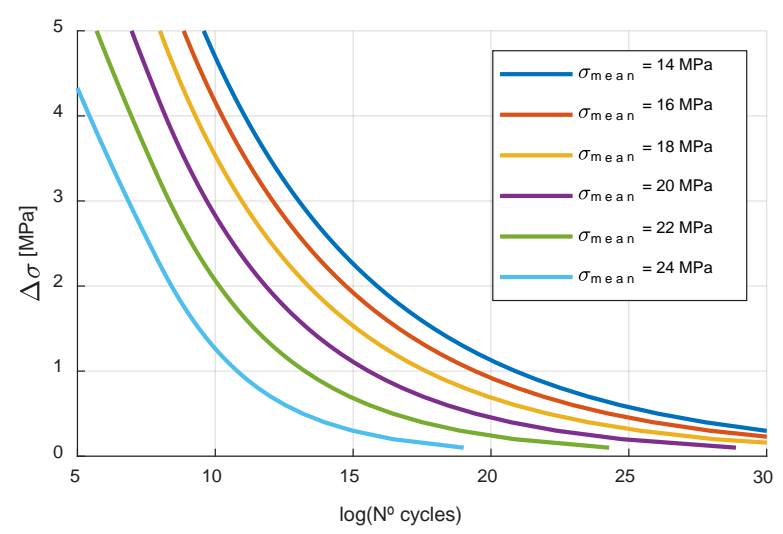

FIGURE 8: MODEL CODE 10 S-N CURVES

The fatigue damage has been obtained for 10-min simulations. To upscale the damage to a yearly damage the mean damage of the six seeds per LC is multiplied by 6 times, by 24 hours, by 365 days and by the probability of occurrence of the wind-wave climate specific to each LC.

Figure 9 shows the Markov matrix for 1 year at the North point of the Tower Base ( $\mathrm{N}$ in Figure 7). The results show a concentration of the cycles for a range tension below $0.1 \mathrm{MPa}$ and a mean value of $15 \mathrm{MPa}$, which corresponds to the combined effect of presstress and $\mathrm{Fz}$ (the weight) with very small moments.

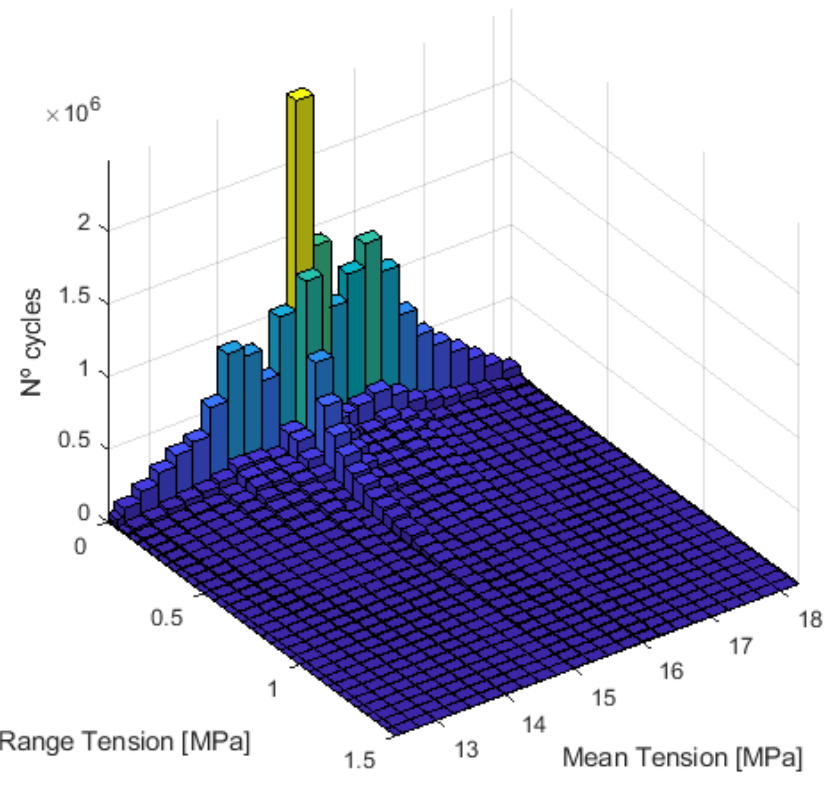

FIGURE 9: MARKOV MATRIX FOR 1 YEAR

The maximum damage per year produced is $6.18 \cdot 10^{-9}$. Table 5 shows the damage per year at sixteen positions on the external perimeter of concrete. In addition, Table 5 shows the estimated fatigue life at each position. The minimum fatigue life of the section is about $1.62 \cdot 10^{8}$. This fatigue life is $3.24 \cdot 10^{6}$ times 
larger than the design fatigue life of 50 years. Therefore, it can be stated that a very conservative design was used for the given section and material characteristics. The most damaged point is the SSE point, as was to be expected, aligned with the predominant powered wind comes from the opposite direction (Figure 3).

TABLE 5: 1 YEAR DAMAGE AND FATIGUE LIFE FOR WINDCRETE

\begin{tabular}{ccccc}
\hline Point & S & SSW & SW & WSW \\
\hline 1 year Damage & $3.75 \mathrm{E}-09$ & $3.33 \mathrm{E}-10$ & $1.18 \mathrm{E}-10$ & $1.04 \mathrm{E}-10$ \\
\hline $\begin{array}{c}\text { Fatigue Life } \\
\text { [years] }\end{array}$ & $2.67 \mathrm{E}+08$ & $3.00 \mathrm{E}+09$ & $8.46 \mathrm{E}+09$ & $9.65 \mathrm{E}+09$ \\
\hline Point & $\mathbf{W}$ & $\mathrm{WNW}$ & $\mathbf{N W}$ & $\mathbf{N N W}$ \\
\hline 1 year Damage & $1.42 \mathrm{E}-10$ & $9.16 \mathrm{E}-11$ & $2.25 \mathrm{E}-10$ & $7.40 \mathrm{E}-10$ \\
\hline $\begin{array}{c}\text { Fatigue Life } \\
\text { [years] }\end{array}$ & $7.06 \mathrm{E}+09$ & $1.09 \mathrm{E}+10$ & $4.44 \mathrm{E}+09$ & $1.35 \mathrm{E}+09$ \\
\hline Point & $\mathbf{N}$ & $\mathbf{N N E}$ & $\mathbf{N E}$ & $\mathbf{N E E}$ \\
\hline 1 year Damage & $5.11 \mathrm{E}-10$ & $1.31 \mathrm{E}-10$ & $3.36 \mathrm{E}-11$ & $6.93 \mathrm{E}-12$ \\
\hline $\begin{array}{c}\text { Fatigue Life } \\
\text { [years] }\end{array}$ & $1.96 \mathrm{E}+09$ & $7.61 \mathrm{E}+09$ & $2.97 \mathrm{E}+10$ & $1.44 \mathrm{E}+11$ \\
\hline Point & $\mathbf{E}$ & $\mathbf{E S E}$ & $\mathrm{SE}$ & $\mathrm{SSE}$ \\
\hline 1 year Damage & $6.72 \mathrm{E}-12$ & $3.91 \mathrm{E}-11$ & $1.51 \mathrm{E}-09$ & $6.18 \mathrm{E}-09$ \\
\hline $\begin{array}{c}\text { Fatigue Life } \\
\text { [years] }\end{array}$ & $1.49 \mathrm{E}+11$ & $2.56 \mathrm{E}+10$ & $6.62 \mathrm{E}+08$ & $1.62 \mathrm{E}+08$ \\
\hline
\end{tabular}

In order to optimize this preliminary conservative design of the platform several strategies can be applied: a reduction of the thickness of the tower base and/or a reduction of the characteristic strength of the concrete. Both strategies imply a reduction of the fatigue resistance of the section but will also result in a more cost effective platform design.

A sensitivity study of the effect of varying the characteristic strength of the concrete is performed in order to evaluate the reduction of the fatigue resistance. The reduction of the characteristic strength of the concrete will close the mean stress and the fatigue strength, increasing the damage. Compressive strengths of $80,70,60$ and $50 \mathrm{MPa}$ are selected for this sensitivity analysis.

The resulting one year damage and the estimated fatigue life for the most critical point of the tower base section depending on the compressive strength are shown in Table 6 . The results notice a clear reduction of the fatigue life of the section as the strength is closer to the mean stress value. Figure 10 shows the evolution of the 1 year damage of the section for the different $f_{c k}$. The reduction of the damage is clearly logarithmic with the concrete strength. For the $50 \mathrm{MPa}$ concrete the fatigue life is less than the span life with a value of 16 years while for the others compressive strength the fatigue life is larger than 50 years.

TABLE 6: 1 YEAR DAMAGE AND FATIGUE LIFE FOR DIFFERENT CONCRETE COMPRESSIVE STRENGTHS

\begin{tabular}{ccccc}
\hline $\boldsymbol{f}_{\boldsymbol{c} \boldsymbol{k}}$ & $\mathbf{8 0} \mathbf{M P a}$ & $\mathbf{7 0} \mathbf{M P a}$ & $\mathbf{6 0} \mathbf{~ M P a}$ & $\mathbf{5 0} \mathbf{~ M P a}$ \\
\hline $\begin{array}{c}\text { 1 year } \\
\text { Damage }\end{array}$ & $6.18 \mathrm{E}-09$ & $2.08 \mathrm{E}-07$ & $2.55 \mathrm{E}-05$ & $6.22 \mathrm{E}-02$ \\
\hline $\begin{array}{c}\text { Fatigue Life } \\
\text { [years] }\end{array}$ & $1.62 \mathrm{E}+08$ & $4.80 \mathrm{E}+06$ & $3.92 \mathrm{E}+04$ & $1.61 \mathrm{E}+01$ \\
\hline
\end{tabular}

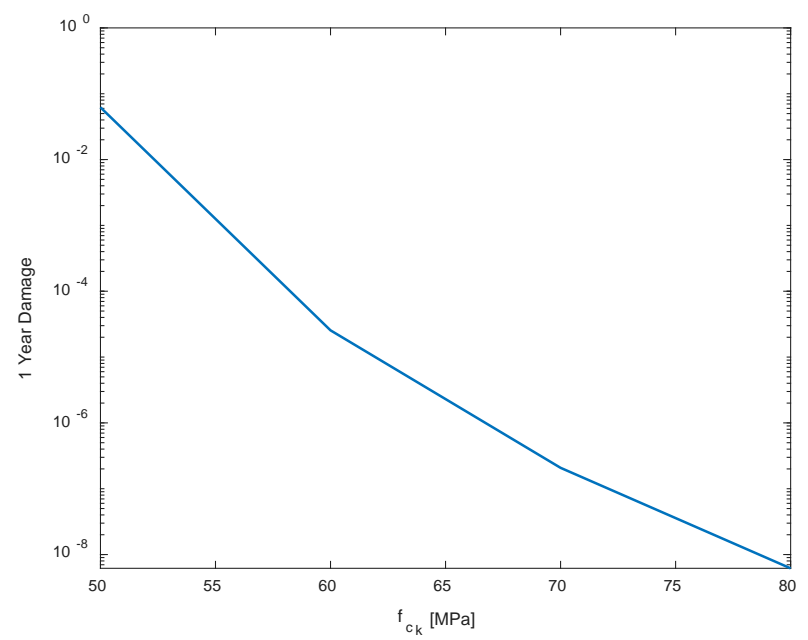

FIGURE 10: 1 YEAR DAMAGE AS A FUNCTION OF THE CONCRETE COMPRESSIVE STRENGTH

\section{CONCLUSIONS}

The fatigue verification of the WindCrete platform shows the good behavior of the platform under the loads occurring at the Gulf of Lion.

A fatigue analysis of 458 different sea states and wind combinations is performed using 6 seeds simulations of 10 minutes each. The metocean data is obtained from the Puertos del Estado SIMAR database and FAST software is used to carry the simulations.

The results show a fatigue life of $1.62 \cdot 10^{8}$ years for the proposed design of the WindCrete.

A sensitivity analysis of the variation of the concrete compressive strength from 80 to $50 \mathrm{MPa}$ is performed in order to adjust the design and reducing the material costs. The results show a clear reduction of the fatigue life of the structure with the reduction of the concrete strength. When the mean stress, mainly due to the axial and prestressing, approaches to the concrete strength, the damage increases logarithmically. For the $50 \mathrm{MPa}$ concrete strength, the fatigue life is reduced to less than 20 years, while for the $60 \mathrm{MPa}$ and over the concrete the fatigue life is larger than the span life of the structure.

Presstressing concrete is key factor for a floating concrete platform design. The prestressing avoids concrete to crack which makes concrete much more durable. However the amount of prestress should be carefully analyzed in order to reduce costs but ensuring the structural integrity through the structure lifespan. 


\section{REFERENCES}

[1]

Fédération internationale de la précontrainte. Working Group on Concrete Ships., 1986, Design and Construction of Concrete Ships: FIP Recommendations., T. Telford.

[2] Fédération internationale de la précontrainte., and Structural Engineers Trading Organisation., 1996, Durability of Concrete Structures in the North Sea., SETO.

[3] "Windcrete | Concrete Floating Platform for Wind Turbines”. Available: https://www.windcrete.com/. [02May-2019].

[4] "FLOATGEN Wind Power Going Further Offshore". Available: https://floatgen.eu/en. [02-May-2019].

[5] Wells, J., 2016, "Life Cycle Analysis of a Floating Offshore Wind Turbine,” Universitat Politècnica de Catalunya.

[6] British Standards Institution, 2008, "Eurocode 2 Design of Concrete Structures. Part 1-1: General Rules and Rules for Buildings."

[7] FIB, 2013, "Model Code 2010,” fib Model Code Concr. Struct. 2010.

[8] DNVGL, 2018, "DNVGL-ST-C502 Offshore Concrete Structures," Standard.

[9] Wilkins, E. W. C., 1956, "Cumulative Damage in Fatigue," Colloquium on Fatigue / Colloque de Fatigue / Kolloquium Über Ermüdungsfestigkeit, Springer Berlin Heidelberg, Berlin, Heidelberg, pp. 321-332.

[10] Campos, A., Molins, C., Gironella, X., and Trubat, P., 2016, "Spar Concrete Monolithic Design for Offshore Wind Turbines," Proc. Inst. Civ. Eng. - Marit. Eng., 169(2), pp. 49-63.

[11] DNV GL, 2016, "DNVGL-ST-0437 Loads and Site
Conditions for Wind Turbines,” (November).

[12] "Prediccion de Oleaje, Nivel Del Mar ;

Boyas y Mareografos Puertos.Es”. Available: http://www.puertos.es/es-

es/oceanografia/Paginas/portus.aspx. [06-May-2019].

[13] Jonkman, J., Butterfield, S., Musial, W., and Scott, G., 2009, "Definition of a 5-MW Reference Wind Turbine for Offshore System Development," Contract, (February), pp. 1-75.

[14] Morison, J. R., Johnson, J. W., and Schaaf, S. a., 1950, “The Force Exerted by Surface Waves on Piles," J. Pet. Technol., 2(5), pp. 149-154.

[15] Campos, A., Molins, C., Gironella, X., Alarcón, D., and Trubat, P., 2015, "Experiments on a Scale Model of a Monolithic Concrete Spar for Floating Wind Turbines," Proceedings of EWEA Offshore 2015 Copenhagen, p. 10.

[16] Campos, A., Molins, C., Gironella, X., Trubat, P., and Alarcón, D., 2015, “Experimental Rao’s Analysis of a Monolithic Concrete Spar Structure for Offshore Floating Wind Turbines," Proceedings of the 34th International Conference on Ocean, Offshore and Arctic Engineering. OMAE 2015, St. John's, NL, Canda, pp. 19.

[17] Plou, P. A., 2016, "Theoretical Research on the Behaviour of Floating Offshore Wind Turbine Concrete Structures under Fatigue,” Universitat Politècnica de Catalunya.

[18] ASTM E1049, 1985, "Standard Practices for Cycle Counting in Fatigue Analysis,” ASTM Stand. 